\title{
Education in Emergency: Exploring the Issues and Options for Continuing Education during Flash Flood in the Haor Regions of Bangladesh
}

\author{
Zawad Ibn Farid ${ }^{*}$, Sawban Ibn Farid², Muhammad Awfa Islam ${ }^{3}$, Tasnim Jerin ${ }^{4}$ \\ ${ }^{1,3}$ Institute of Disaster Management and Vulnerability Studies, University of Dhaka, Dhaka-1000, Bangladesh \\ ${ }^{2}$ Department of International Relations, Jahangirnagar University, Dhaka-1000, Bangladesh \\ ${ }^{4}$ Department of Coastal Studies \& Disaster Management, University of Barishal, Barishal-8254, Bangladesh \\ DOI: https://dx.doi.org/10.51584/IJRIAS.2021.6406
}

\begin{abstract}
Bangladesh, being overly surrounded by rivers, is a highly flood-prone country. Geographical location and features make this country prone to Flash Floods in definite areas commonly known as Haor regions. During the monsoon, the community's children find it immensely difficult to go to schools since the water level rises and connecting roads get inundated. During a Flash Flood, they are denied by the disaster to continue their education at schools, resulting in dropouts, loss of academic years, and even social problems like early marriage. Vulnerable conditions rooted in fragile socio-economic condition, seasonal unemployment, economic hardship, along with attitudinal vulnerability, results in disastrous impacts when faced with Flash Floods. Children of the community are the worst sufferers as they are forced to leave schools which then traps them into a never-ending vicious loop of vulnerability and poverty. This paper adopts a method of reviewing relevant secondary documents and the authors' direct observation from their field visits to address the issues and way forward pertinent to continuing education in the Haor regions during disasters. The paper's findings suggest that poverty, marginalization, historical inequality etc., are the root causes of the progression of vulnerability in the areas of study. The paper further describes the impacts of disaster on student and institutional facility,ranging from an individual loss like dropouts to broken water and sanitation facility at schools. This article also points out critical specific options to be undertaken at the local and national for addressing this issue, i.e., creating a standardized manual to be used nationally.
\end{abstract}

Keywords: Education in Emergency, Flash Flood, Haor Regions, Continuity of Education, Children, Students.

\section{INTRODUCTION}

B eing one of the major natural disasters that the Bangladeshi population confronts regularly, Flooding is a persistent incident that affects people in diverse ways in Bangladesh. Each substantial flooding occurrences generally affect $20.5 \%$ of the country's total area, but sometimes it can be quite destructive by submerging more than $60 \%$ of the country (Paul and Routray, 2010). Rather than regularFlooding by a river stream, unusual flooding events like Flash Flood likewise occur in Bangladesh periodically, causing demolition of houses, infrastructures, livelihoods sources, properties, life losses, and enormous sufferings to the affected people (Abedin and Khatun, 2019). A Flash Flood is the type of flood, which is generally caused by extreme rainfall in a short time interval over a relatively more minor region; it is referred to as the term Flash Flood. During a Flash Flood, water level rises and decreases quite rapidly with no or little warning (Bhattacharya and Suman, 2012). The immensely flashy physical appearance of the river basins and excessive sudden rainfall in the particular area causes the Flash Floods in the northeastern Haor regions (BWDB, 2014). The Haor area, which is otherwise denoted as the Sylhet basin or the Haor basin, is projected to cover 25,000 and 4,450 square kilometers, while the entire area of Haor alike wetland ecosystem in the country is around 80,000 square kilometers. Every time the monsoon impacted Flash Floods in Haor areas leave damaging effects in distinguished sectors, e.g., livelihood, food security, agricultural goods production, gender susceptibility, water and sanitation, social vulnerabilities, education system, healthcare, and economically marginal groups (Kamruzzaman and Shaw, 2018; NPDM, 2017). However, among all the adverse impacts, disasters like recurrent floods affect the children's one of the most significant rights, the right to education, besides displacing and separating them from their families. However, the consequences of prolonged Flash Floods on children's access to education and implications on ways to continuing education received less attention than other priority areas, e.g., providing food, shelter, and other emergency aid during a flood (Akram, Chakma, and Mahbub, 2012).

Analogous previous studies show that children can get affected by the consequences of floods in different ways in broad lines, i.e., in the school, on their way to school from home or on the way from school to household, in homes and schools both as these can collapse. Again, the adverse consequence of such floods can lead to loss of livelihoods, which often results in insecurity of food and commodities (Chang, Khatoon, and Shah, 2013). Events similar to Flash Floods repeatedly result in missed schooling days and immensely delayed academic development, missing social opportunities, increased dropouts, and augmented exposure to different life stresses, such as illness, malnutrition, and even death (Peek, 2008). Furthermore, per the summary of the framework developed by Okuom et al. (2012), the 
vulnerabilities of children are increased by different natural disasters in various contexts. The framework identifies and categorizes distinct factors, which generally contribute to their vulnerabilities, i.e., house-related, environmental, infrastructural, and factors related to study and students. The impacts of disasters such as floods on school facilities must not be premeditated only in terms of the necessity for preventing appalling damages that might demolish the infrastructures but also concerning the preservation of children's lives during disasters like floods.

In the education sector, considering the frequently Flash Flood-hit Haor regions, floods leave a trace of destructions and damages that can result in children's education getting $n$ such a level where it is irrecoverable. In every Flash Flood occurrence, schooling of children gets cancelled, a large portion of children face dropout from along with the incidents of school absenteeism frequently occurring, as school buildings are utilized as emergency shelter centers (Nipa and Ahmed, 2017). Following this, there exist the widespread practice that schools are usually designated as emergency evacuation shelter centers by local government authorities according to the central disaster plans and policies. While a classroom in a particular school in a flood-prone area offers reasonably ample space for the gathering in need, the shelter seekers often bring their cattle into the site and use the infrastructure to house those cattle or animals. Sequentially, this results in pathetic situations in the schools, which disheartens the teachers and students. When schools get closed and stay closed for more extended periods for Flash Flood causing disturbances, the girl students are more unprotected to other substantial risks such as early marriages (Save the Children, 2017).

As of three recent consecutive devastating Flash Floods of 2016, 2017, and 2019 in Haor regions of Bangladesh, it can be seen from several sources that the number of educational institutions affected by Flash Flood has faced a growing pattern across the Haor regions as new areas of the northeastern regions are being flooded in every flood occurrence. Monsoon flooding caused by heavy rainfall has severely affected the educational activities in around 4,000 primary and secondary level schools, madrasas, and colleges in northeastern and northern districts of Bangladesh (Hasnat, 2017; Quayyum and Chowdhury, 2017). A significant number of schools had to shut down on account of the declining attendance of the students, who took shelter in emergency flood shelter centers with their families. Additionally, their educational tools and instruments, e.g., textbooks, notes, pens etc., got drenched, lost or damaged, and different terms of the exams had to postponed. In each occurrence of such Flooding, floodwater enters the classrooms of primary and secondary schools, and the buildings faced worse damage in many cases (Bhadra, 2019). For instance, in the Flash Flood of 2017, a total of 1,946 primary level schools alone had been closed in the northern part of the state, as the classrooms in almost all of these schools were rapidly flooded, while a further 587 schools were designated and utilized as emergency flood shelter centers (Hasnat, 2017). Moreover, school-going children in Flash Flood-hit areas of Sunamganj and Moulvibazar districts of Sylhet division of Bangladesh have to remain absent from school for almost half of the year per annum, mainly because there are waters all around, making it difficult for them to travel and on the other hand, parents want them to help out in saving crops submerged underwater (Deshwara and Eagle, 2017; Deshwara, 2016).

Compared to other developing nations, Bangladesh has shown comparatively good development in the primary education sector, especially in gender parity and enrollment. However, substantial challenges and gaps remain with reference to education quality, repetition rate, competencies, and rate of dropouts (Education Watch, 2009). Nevertheless, the question remains whether Bangladesh could have minimized these issues and achieved much better progress had the floods' impacts been mitigated in education during the emergency, as many Bangladeshi schools are situated in frequent Flash Flood-prone areas.In addition, the elevation of natural catastrophe caused by climate change, such as Flash Floods,is growing in severity and inconstancy in Bangladesh. Disasters are fetching cataclysmic character as they are frequently unexpected in nature, deadly, consequential and often cause damage and death in terrible incidents (Coronese et al., 2019). It has become one of the main apprehensions regarding the humanitarian issue and causing risk to achieve Sustainable Development Goals (SDG), particularly the fourth point. School-going children are the most exposed, still stepped in group during the disaster. Though the impact of a flood on the socio-economic prosperity of children have been well recorded, the effects on children's possession and approach to quality education have got less recognition (Masese et al., 2012). It has caused a deficiency in the research on impacts of floods on school-going children and academic framework in Bangladesh and coining way-outs from this mishap through the continuum of education during Flash Floods.

Therefore, this study aims to assess the impact of Flash Flood on pre-primary, primary and secondary education that takes place almost every year in the Haor region of Bangladesh. Furthermore, the study seeks to identify problems of continuing education during Flash Flood in Haor with a focus on multi-level interfaces analyzing the secondary database. This article also aims to determine the students' specific vulnerabilities in terms of accessing the educational facility. Finally, the article attempts to identify appropriate options for continuing primary and secondary education during Flash Flood coining suitable recommendations as per the context.

\section{METHODOLOGY OF THE STUDY}

The study has synthesized the impacts of Flash Floods on the education sector of Haor regions and the and vulnerabilities of students of the particular region to point out robust, sectorspecific, and feasible options to continue education during the on-set Flash Flood disaster principally. Hence, it is an analytical review through content analysis procedure based on secondary data sources. However, all the authors visited the 
study areas and interviewed local people randomlyto get the absolute big picture of the susceptibilities in terms of the education system in Haor communities. Personal observation of the authors has also been reflected in the findings of the study. Besides, a rigorous review of appropriate and credible literature sources took place to accumulate the study findings. Original research journal articles of indifferent subject matter were exploited principally to review the status-quo to receive an in-depth picture of the focus. For peer-reviewed scholarly articles, the study's authors used the Mendeley search engine, Microsoft Academic, and Google Scholar. Besides the reviews of relevant peer-reviewed journal articles, research reports, working papers, and substantial newspaper articles to better understand the issues. These relevant secondary data for analyses were collected from different documents and reports of Government and Non-Government agencies. The authors of this research study appropriately recognized all the ethical aspects. All the sources of information utilized in this paper are accredited and scientifically referenced.

\section{FINDINGS}

\section{A. Education Stream Framework in Bangladesh}

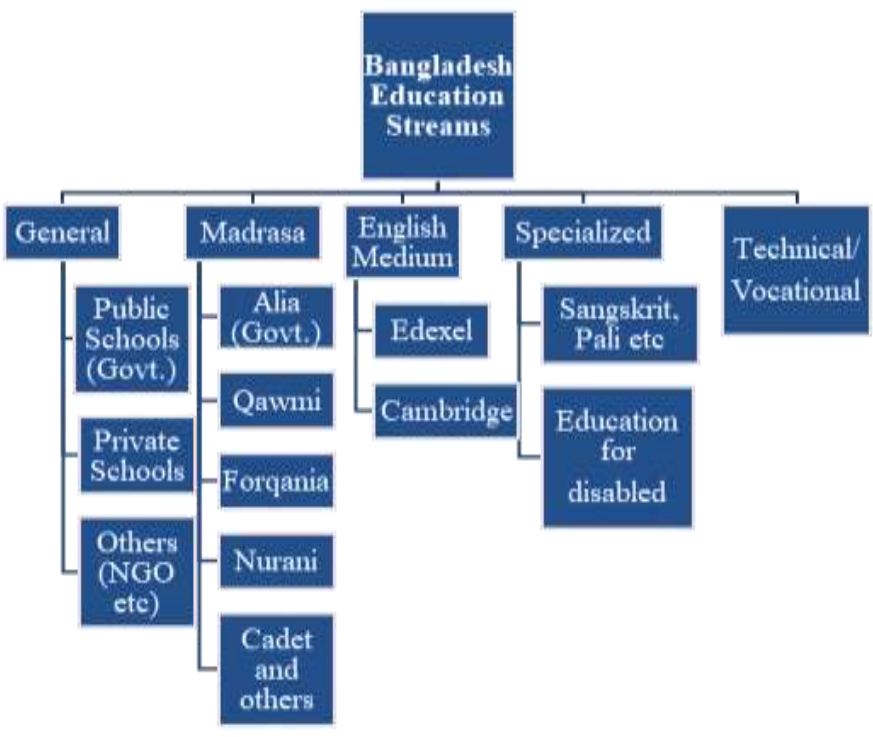

Fig. 1 Education Stream of Bangladesh in Different Levels (Adopted from BANBEIS, 2015).

To understand the vulnerabilities and impacts of Flash Flood on students of different levels, it is required to overview the current education system of Bangladesh. According to BANBEIS (2015), Bangladesh's educational framework contains both conventional and non-conventional component. The conventional system is distinct as traditional, framed in order, sequentially classified schooling from initial to subsequent level (BANBEIS, 1999). Fig-1 shows that Public schools under government authority provide conventional Primary education, Private schools and NGO authorized schools. Non-conventional system asserted as particular systematized education system apart from the conventional system targeted to explicit goals and to provide particular groups (BANBEIS, 1999).

Fig. 1 shows several parts of the non-formal educational system. Initially, Adult Education targeting to provide efficiency in basic skills such as numeracy and literacy to uneducated population over the age range of least 15 years. Then a complementary system to conventional education aiming to offer primary education to the particular group of children who are dropouts, irregular or unable to ensure full condition to be enrolled in primary education. The next stream is education based on the British syllabus. Finally, the madrasa education system focuses on Islamic theology rather than relying on the grade they rely on the subject. One of the streams, Alia Madrasa, is authorized by the government. Another stream, "Qawmi Madrasas", are autonomous and self-authorized. "Forqania" and "Nurani" systems, two branches of Qawmi madrasa, specially dedicated to children education (BANBEIS, 2015).

\section{B. Impacts of Flash Flood on Education Sector in Haor Area}

Flash Floods in Haor areas mostly occur during the monsoon season between the month of June-July and SeptemberOctober, affecting a large amount of land across the country (BWDB, 2014). Impacts of such rapid on-set floods are manifested through loss of lives, damage to asset and properties, environmental disruption, interruption of services and social functions, livelihood disruption, and cause physical and mental distress among the affected children. Likewise, it deleteriously affects children's education. It can be seen from the past Flash Flood events in Haor regions that schools' infrastructure gets damaged, educational activities get disrupted, and children and their families get displaced due to floods. Consequently, the children become physically and emotionally distressed and deprived. The form of suffering includes but are not limited to loss of education hours and learning materials and limited access to school. These sufferings work as a factor of degrading scholastic performance, increasing dropout rates and inaccessibility to the fundamental right of education (Nipa and Ahmed, 2017). However, assessing the substantial impacts of Flash Flood in northeastern Bangladesh as per the espial of filed from Flash Flood affected Sunamganj district aligned with the reporting ofSave the Children (2017); Hasnat (2017); Quayyum and Chowdhury (2017); Bhadra (2019); and Deshwara and Eagle (2017), the following precise aspects can be considered as the common problems caused by Flash Floods:

Firstly, most of the schools in the Flash Flood-prone Haor region are positioned in a vulnerable geographical location, and their condition is very fragile which cannot withstand a flood.

Secondly, schools that do not get affected by the flood are generally used as flood shelter for the affected people. As a result, students cannot attend schools due to an unfavourable 
study environment even if their schools do not get affected. This causes additional loss of school time to the students.

Thirdly, the local economy of the affected regions gets disrupted, and for survival, poor and affected families have to engage their children in income-related activities

Fourthly, absence of an institutional preparedness plan and system from school to the national level for the continuity of education during a flood.

Fifthly, schools are regarded as an establishment for risk reduction in disaster preparedness activities, hardly realizing the negative impacts on education by disasters.

Sixthly, there is not any significant coordination and linkage between education and flood management, and minimal focus is given to Disaster Risk Management (DRM) in terms of policy and practice. This was explicitly noticed from field observation in Sunamganj district; and

Seventhly, there are no clear and specific DRM actions that address education in emergency, and there are no well-defined roles of education and disaster management.

\section{Sectoral Impact of Flash Flood on Education System in Haor Regions}

Communication system gets seriously affected due to Flash Flood as it directly damages the roads and other transport systems. It also damages the school infrastructures, e.g., classrooms, playgrounds, water and sewage system, teaching and learning equipment. Hence, this kind of on-set flood disaster is accountable for interrupting the entire education system sector-wise (TABLE I).

Table I: Sector-wise impact of Flash Flood on education system in Haor

\begin{tabular}{|c|c|c|c|}
\hline $\begin{array}{l}\text { Plan and } \\
\text { Policy } \\
\text { (Activity) }\end{array}$ & $\begin{array}{l}\text { Amenities and } \\
\text { Resources } \\
\text { (Loss in terms of } \\
\text { Resources) }\end{array}$ & $\begin{array}{c}\text { Functions } \\
\text { and Delivery } \\
\text { (Loss in } \\
\text { terms of } \\
\text { functions and } \\
\text { delivery) }\end{array}$ & $\begin{array}{l}\text { Accessibility and } \\
\text { Engagement } \\
\text { (Short- and Long- } \\
\text { Term Losses) }\end{array}$ \\
\hline $\begin{array}{c}\text {-Use of } \\
\text { schools as } \\
\text { shelter; } \\
\text {-Not having } \\
\text { any } \\
\text { preparedness } \\
\text { plan } \\
\text {-School repair } \\
\text { and } \\
\text { reconstruction }\end{array}$ & $\begin{array}{c}\text { Damage to } \\
\text { classroom, water } \\
\text { supply, sanitation } \\
\text { facilities, furniture } \\
\text { and other } \\
\text { equipment/teaching } \\
\text { learning materials. }\end{array}$ & $\begin{array}{l}\text {-Classroom } \\
\text { activities \& } \\
\text { learning } \\
\text { sessions are } \\
\text { postponed; } \\
\text {-Water } \\
\text { supply and } \\
\text { sanitation } \\
\text { service } \\
\text { become non- } \\
\text { functioning; } \\
\text {-Recreational } \\
\text { activities are } \\
\text { unattainable; }\end{array}$ & $\begin{array}{c}\text {-Attendance rates } \\
\text { diminish because } \\
\text { of displacement, } \\
\text {-Emotional and } \\
\text { physical distress, } \\
\text {-Losses of learning } \\
\text { materials, } \\
\text {-Unavailable } \\
\text { sanitation service, } \\
\text {-Submerged/ } \\
\text { damaged roads, } \\
\text {-Absenteeism of } \\
\text { teachers } \\
\text {-Increased dropout } \\
\text { rates } \\
\text {-Migration, } \\
\text {-Displacement, } \\
\text {-Child labor } \\
\text {-Early marriage }\end{array}$ \\
\hline
\end{tabular}

The floods usually inundate the small link roads and inhibit the accessibility to the education centers from the recurrent flood occurrences. Moreover, Flash Floods cause an unfavourable study environment as they damage the basic amenities like safe water and sanitation facilities, losses of study materials and limit the options for recreational activities (Education Cluster Report, 2015).

\section{Vulnerability and Progression of Vulnerability: Students' Perspective}

There is an intertwined relationship among poverty, marginalization, and vulnerability to disasters and which in turns individually and collectively affect people's life expectancy, income, and education deleteriously (Save the Children. 2017). Following that, from the situational analyses of the Flash Flood affected regions, the following issues can be referred to as vulnerabilities that students of the primary and secondary level face frequently:

1) Poverty: It is widely acknowledged that poverty does have a negative impact on education (World Bank, 2018). It excludes poor people from the rights of education, and this exclusion takes place in various ways. Unprivileged people do not have the solvency to bear the direct costs of education and the opportunity costs. It is seen that the absenteeism rate is high among the children from more impoverished families, and gradually this rate causes them to drop out of school. Moreover, this disturbing their academic performance and ultimately causing poor results (Shohel and Mahruf, 2012). Subsequently, it can be said that poverty works as one of the main reasons for the marginal children's deprivation of the right to education, either because they didnot get enrolled or even if they did, they had to drop out very early. Compared to the wealthiest 20 percent families, the dropout rate is 12 percent higher among the children coming from the most deficient $20 \%$ of families (World Bank, 2013). Concerning the flood disaster-prone Haor areas, the demand-side failure is more devastated due to poverty. To cope with frequent Flash Floods, most children from unprivileged and vulnerable households in these areas have to get involved in different types of work, leaving schools for supporting their families. As the children also must struggle for survival, this limits their access to education, especially at the primary and secondary level. (Quayyum and Chowdhury, 2017; Arredondo, 2016; GoB, 2012). Similarly, it was observed during the field visit that most of the families living in the remotest Haor regions of Bangladesh have a very humble socio-economic status. Their survival is unquestionably more important than anything else, let alone getting their children enrolled in any formal education system.

2) Marginalization: Marginalization is a product of power structure, which is also exaggerated by a disaster like a flood, serves as a hindrance to achieving gender, caste and social class equity. This ultimately constrains the supply side for school accessibility. Marginalized groups and localities always get discriminated against as most of the time, the delivery mechanism of education service and education 
quality is bestowed on the basis of gender, ethnicity, degree of remoteness, andsocial classes. There are teacher shortages in most of the schools in rural Haor areas. Since the schools are located in remote areas, often qualified teachers are less willing to teach in those schools. Furthermore, the matter of concern is that schools with very few teachers do not have proper training, and the absenteeism rate is very high among them. Moreover, it was observed from field visit that due to the vulnerable geographical locations of schools in floodprone unions of particularly inundated Upazilas of Sunamganj, rural children are unable to access the schools during an emergency. Quayyum and Chowdhury (2017) reported the same findings in their study.

3) Regional differences in education: Study (Khan and Islam, 2010) found that the regional differences influence student's learning outcomes. Children from Dhaka and Chittagong districts have better scholastic performance than the national average, whereas the children from Rajshahi and Sylhet districts lags considerably. The urban-rural gap also affects education quality and different passing issues. Gender discrimination is another factor contributing to the girls' inaccessibility to education. Many families in our society hold the wrong perception about girls' education that there is not any necessity for girls to read and write. Despite educating them, they prefer to keep their girls at home taking care of things or household chores and getting married at a very early age. Moreover, insecurity and the risk of sexual harassment of young girls are adding more challenges to this gender disparity. Educational institutions and institutions responsible for disaster management have explicit knowledge about the flood impacts on assets and infrastructure. With this knowledge, they have developed strategies for restoration and reconstruction, requiring financial and material resources to execute. Normally, they get funds from institutional donors for carrying out the restoration and reconstruction work (Trines, 2019).

In consonance with the field observation, regarding theHaor areas, the educational institutions lack knowledge on using education for flood risk reduction and establishing a safety culture. Subjects and issues in the curriculum regarding their specific food risk and risk reduction measures have not been included to date. On the other hand, there is a lack of consideration about children's academic losses within those communities. While restoration and reconstruction activities are undertaken frequently, the priority of improving education and continuing education during an emergency is uncared in the response interventions. Additionally, many schools in flood-prone regions are used as shelter centre for floodaffected people. This causes increased loss of education hours due to the unfavorable study environment at the school. Students have to take initiatives by themselves for making up their lost time as there are not any available technologies and support provisions for assisting them in this case (Education Cluster Report, 2015).
4) Disproportionate school-student ratio: Proximity of the schools is often a problem for many. Since parents need to take their seven- or eight-years older son or girl to school, distance is often a problem for many. During a normal monsoon, the only option for going to school in those regions isa boat, and hence parents feel scared to leave them alone. (Boat School Report- BRAC, 2020). The number of schools in those areas is largely insufficient, and the schools need to accommodate students more than they should do. As a result of which, teachers fail to pay the necessary attention to students they deserve.

5) Other vulnerabilities: There is an inherent lack of awareness regarding children's education among the parents of Haor regions. The statistics describing the literacy rate of Haor areas conform to such a claim. The literacy rate of Haor areas, on average, is $38 \%$ only, whereas the national literacy rate of Bangladesh in 2019 was $74.68 \%$. The contrast is unbelievable yet true. This can be denoted as just the tip of the iceberg. The problem of people being apathetic about formal education is rooted in poverty, seasonal unemployment, economic hardship and many other factors.

\section{E. Education in Emergency: Finding Answers from Global Frameworks}

1) Sendai Framework for Disaster Risk Reduction (SFDRR): Different frameworks have been devised to explore different aspects to be considered while carrying out diverse and different DRR measures. These frameworks have also been instrumental in providing policy guidelines about education in emergency. Sendai Framework of Disaster Risk Reduction (SFDRR) is one of the primary drivers of all DRR activities across different sectors. This framework which has been adopted and agreed upon by almost all countries for the timeframe of 2015-2030, recognized the importance of including disaster preparedness and disaster risk assessment activities in schools - complying with the guideline different humanitarian and development organizations have piloted and implemented projects on School-Based Disaster Risk Reduction (SBDRR). The framework also considers schools as critically important infrastructure. Furthermore, it also calls for carrying out necessary structural and non-structural disaster risk reduction measures. Priority 1 of the framework guides for identifying all the disaster risks associated with the event of a disaster. Priority 3 urges responsible authorities and communities to invest in disaster risk reduction activities for ensuring resilience. All the priorities can, however, be linked with education in emergency for creating an enabling environment that will allow continuity of education even during dire times.

2) The Comprehensive School Safety Framework (CSS): The Comprehensive School Safety Framework (CSS) outlines a detailed structure that is expected to augment disaster risk reduction initiatives, improve student's safety at school and improve the overall safety of the schools. All of these can combinedly contribute towards continuing education even during an emergency. Identifying and extracting different 
essential factors from this framework can be pivotal for continuing education in the Flash Flood affected Haor regions (UNDRR, 2017; Shah et al., 2018). The framework further accentuates collaboration among relevant stakeholders to alignthe education sector and disaster risk reduction efforts (UNDRR, 2017). This framework, therefore, is highly compatible and can be referred to as a practical framework for continuing education during dire times.

3) Sustainable Development Goals (SDGs): The importance of education for all and quality education have been a critical concern in almost all development agendas. The Sustainable Development Goals is no exception to such practices. SDG goal 04 speaks about the value of education. Furthermore, it describes the importance of education that is both inclusive and equitable. It speaks about quality education for all. This goal of the SDG can be very well linked with the problem statement of this article. Flash Flood does not only affect children and students in Haor areas; it is also an impediment towards fulfilling the SDG goals for Bangladesh. Prioritizing children's continuous access to education, the safety of school infrastructures, sites and using education as a tool to assist countries in improving different disaster risk management efforts should be well included within this agenda. (UNDP, 2019).

\section{F. Education in Emergency: Right or Privilege?}

During an emergency, survival becomes the topmost priority. Although education is considered a fundamental right during regular times and given enough importance during an emergency, the reality becomes very different. However, there are many policy frameworks and guidelines prepared by different advocacy groups who vouch for imparting education to children even during dire times. The need for continuing education has been documented in different humanitarian policy and planning initiatives. Inter-Agency Network for Education in Emergency (INEE) and SPHERE standards explains the minimum standards to be followed in different phases of the disasters for continuing education. SFDRR, SDG, along with different regional and local frameworks, i.e., ASEAN, SARC acknowledges the importance of ensuring children's access to education during an emergency. Education has been perceived as children's right in the writing of Wisner et al. (2004). According to Article 28 of the United Nations Children Act, a child has a right to education in different situations. Article 17 of the constitution of Bangladesh describes free and compulsory primary education for all. (Mohajan, 2014). Therefore, while the aforementioned global commitments and policy frameworks deserve appreciation, there is still more to do when it comes to implementing these acts during disasters. A considerable number of children who get affected by Flash Flood every year in Bangladesh is entitled to their basic right of education which they should not be denied because it is prettyapparent that these floods in the study areas do not only deprive children of their basic rights but also force them to leave schools which then leaves the child with an uncertain future.

\section{G. Continuing Education during Flash Flood: Exploring the Feasible Means and Actions}

To continue the education of vulnerable students captivated by Flash Flood, it is imperative that children are offered an environment that is physically, culturally and socially safe. In this regard, the study found the following factors evaluating relevant national and global sources, i.e., progress report of Sustainable Development Goals in Bangladesh (GoB, 2019); World Bank (2013, 2015); Alam (2007); and INEE (2010). These options should be especially considered as plausible implications for continuing education during rapid on-set Flash Flood in the areas by Haor basins as a recommendation criterion.

1) Creating a standardized manual for education in an emergency: First and foremost, a standardized document has to be prepared by the Ministry of Education in consultation with the Ministry of Disaster Management and Relief (MoDMR) and other relevant authorities, which will allow a smooth continuation of education in emergency. Education always need not be directly or physically imparted. Therefore, the roles and responsibilities of all the concerned individuals, i.e., students, teachers, headteachers etc., need to be enlisted. This document will dictate and guide its users to continue education during an emergency, taking all the context-specific needs, vulnerabilities and capacities into its account.

2) Standardized provisions for school facilities duringFlash Flood: Schools will require restoration of their services and reconstruction of the damaged infrastructure and furniture when hit with an erratic disaster like Flash Flood. Alternative arrangements can be made for classrooms if required. Besides, supplying teaching and learning materials to students must be carried out through a standard provision.

3) Flood specific water and sanitation facilities in institutions: School's water supply and sanitation facilities usually get moderately or severely damaged depending on the intensity of the disaster. After the disaster, when the schools are reopened, authorities fail to restore the necessary facilities due to lack of adequate funding. On the other hand, children spend long hours in school without having access to safe water or decent sanitation facilities. Children are heavily discouraged from comingto schools in the face of such difficulty. The facilities at schools need to be restored considering the future disasters into account. The climate change-induced uncertainty must be considered while reconstructing or renovating the infrastructures. The principle of build back better is more appropriate in this context.

4) Changing rooms for children during a flood: Observation from school visits revealed that there are no changing rooms for children in the school. The washrooms are dirty and often unusable. During the occurrence of Flash Floods in Haor areas, many children get drenched in water unintentionally and get their clothes wet while coming to schools. The problem is acuter when seen from an adolescent girl's lens. Girls are often subjected to verbal or physical abuse due to 
this problem. Changing rooms can be allocated for both girls and boys separately so that they can dry them up or change clothes. The privacy of the students must be monitored. The female teachers can be given the responsibility to ensure the protection of the girls.

5) Transportation facilities towards educational institutions: Teachers and students both face difficulty using partially or fully damaged roads, connecting roadsquickly inundated after heavy rainfall and muddy roads. Repairing damaged roads take time. Hence, alternative arrangements must be made for bringing teachers and students to schools. Arrangement of necessary boats for students only from the government can be an excellent solution to this problem. These boats should cost students lower than usual. Arrangements for picking up students from their homes or from easily accessible points can also be made if possible.

6) Allocation of additional budget for education in an emergency:Flash Flood is a regular phenomenon in Haor regions. Hence, preparedness is the key toan effective and efficient response. During an emergency, food, safe drinking water and other necessary logistics are required for continuing education. Government must financially aid those students who are in need, and an emergency fund can be created. Channeling of money through corporate social responsibility (CSR) funds or simple donations or charity can be other probable options to ponder. GO-NGO-Private sector collaboration can also play a vital role in raising such fund.

7) Alternative method for lesson delivery: On one hand, teachers may need to forego traditional modes of teaching that they are used to; on the other hand, the students, which include children from different age groups, must adopt a learning process outside traditional setup. Therefore, both the teachers and students should be supported in preparing, imparting and receiving alternative method for lesson delivery. The lesson may include assignment-based assessment, distance education, recorded classes etc. Covid19, despite its adverse impacts, have helped us in this process of alternative learning.

8)Child-Friendly Space (CFS) during a flood:The observation of the study team suggests that there are no child-friendly spaces available in that particular area, and when the community members were asked whether CFS are set up during an emergency, they replied in the negative. For protecting children against abuse, violence and exploitation during Flash Floods in Haor areas, Child-Friendly Space (CFS) can be established by local administration and schools. Teachers and volunteers can collaborate with Child-Friendly Space. This will also allow continuing educational activities through such spaces (UNICEF, 2018).

9) Education material management during a flood: Schools usually store different textbooks, academic and non-academic books within the particular premises. Other documents are essential for the school authority. Schools often have a library. During a flood, since many schools are inundated, and many are used as shelters, the management of different educational material and different important documents of the schools becomes a difficult task. All the documents must be stored safely or kept within a safer place within that school compound when Flash Flood occurs.

10) Volunteer teaching staffs: Children need more attention during disasters. When their schools are closed, they may get depressed or frustrated. There might be educated people in that area who can take care of them voluntarily. Educated college or university going students can volunteer and should be brought under a planned venture.

11) Addressing the requirements of affected teachers and education personnel: Flash food does not only impact the lives of the school-going children only somewhat; it also adversely impacts the lives of teachers, staffs and their families too. It is redundant to state that loss of livelihood, property, or asset heavily affects individuals' physical and mental state. Such adversities refrain teachers from becoming fully functional even when the disaster is over, and it is hard for the individuals to concentrate fully. Therefore, it is highly required that teachers and staff get assistance in cash or kind if required and should be appropriately compensated.

12) Awareness about continuing education:One of the significant findings from the observation of the study team is that many families, due to the loss incurred from the flood, loses their ability to afford the expenditure of formal education of their children. They engage their children in different income generating activities, resulting in dropout or loss of academic year or unsatisfactory result. Often, due to recurrent disasters, parents become apathetic about sending their children to school. The parents start considering the educational expenses as a burden. The problem is far more acute for the girls who become more vulnerable to social problems like early marriage. The local government, along with non-governmental organizations, must conduct courtyard meetings and campaigns to raise awareness among the parents of the disaster affected areas.

13) Introducing an effective flood resilient education system: For an uninterrupted education system during a flood, the Government of Bangladesh should partner up with different development agencies for creating a robust or resilient system. The system must focus on increasing the capacity of the communities via better preparedness for effective response. Researchers' observation reveals that community members are first responders and act as volunteers in different disasters, which means necessary knowledge, skills and training must be imparted targeting the community members as well. Wisner et al. (2004) rightly pointed out that the students perceive schools not just as an education site, instead they enjoy being in the classroom with their friends. Furthermore, important social learnings are instilled in them through the process of "learning through fun." Hence, an effective flood resilient education system needs to be installed, monitored and updated regularly. 
14) Replicating successful models:The on-ground observation of the researchers provided this study with a new insight into innovative programs implemented by development partners to continue education during an emergency. BRAC's one of the most successful interventions in Haor areas named "Boat Schools" has received global recognition and has been enlisted as one of the innovative projects towards achieving equity in education. Since the students of Haor areas cannot go to school during Flash Floods, even during monsoon, BRAC decided schools will come to them. They partnered up with the Government of Bangladesh, and their curriculum was well accepted, and permission to sit for the primary school certificate exam was provided to the students who got enrolled under this boat school program. With an astonishing 99\% passing rate, this intervention has proven how capable the students of Haor regions are. All they need is a little push and support. Interventions like this can be replicated by further GO-NGO collaboration (BRAC, 2019).

\section{CONCLUSIONS}

Notably, as a least developed state, Bangladesh has gained relatively higher enrollment in education rate and gender equivalence of children at both primary and secondary levels of education. The country, nevertheless, is frequently and colossally prone to several natural disasters. The term "Living with disasters" applies perfectly for the communities living in Flash Flood prone Haor areas since antagonistic impacts resulting from flood and Flash Flood occur at consistent intervals in Haor basins. According to these phenomena, it is a clear picture from the findings of the paper that the children of these regions suffer a great deal of loss in terms of academic instruments, learning opportunities, and from the least access to their schools for as a consequence of extensive inundation caused by Flash Flood. As a consequence, loss of valued education hours happens, which results in diminishing academic performances and an augmented dropout rate. For an uninterrupted educational continuity, there is a need to understand and profoundly engage with the institutional, physical, and organizational contexts of the academic arenas, as a proper understanding of relevant capacities and vulnerabilities of the stakeholders of the at-risk schools must engage in central strategic practices for the flood-affected areas.

Accordingly, enabling the policy and environment, strengthening coordination and communication amidst school stakeholders, government, along private sectors can lead to the integration of disaster risk reduction into sectoral policies for averting disrupted learning activities in Flash Flood induced schools. It is likewise fundamental that the national education policy of Bangladesh delivers the feasible guidelines for continuing education during such on-set Flash Floods. Despite the damaging characteristics of such floods, institutions in both disaster management body and education sectors must redefine their influential roles and capabilities to help the affected children of Haor areas to access the required education persistence satisfactorily. Therefore, clearly, there is a decisive necessity to develop better and appropriate measures to prepare and alleviate the effects of the Flash Floods in the education sector of Haor basins of Bangladesh. Above all, the aim to reimburse the education system focusing on the continuity during Flash Floods must involve all the relevant stakeholders to enhance children's resilience to floods by undertaking necessary policies and eventually translating those policies into meaningful actions.

\section{REFERENCES}

[1] Abedin, J., \& Khatun, H. (2019). Impacts of Flash Flood on Livelihood and Adaptation Strategies of the Haor Inhabitants: A Study in Tanguar Haor of Sunamganj, Bangladesh. The Dhaka University Journal of Earth and Environmental Sciences, 8(1), 4151 .

[2] Akram, O., Chakma, J., \& Mahbub, A. (2012). Continuing education in disaster-affected schools in Bangladesh: an evaluation of the Education in Emergencies Project. Children Youth and Environments, 22(2), 249-262.

[3] Alam, K. (2007). Disaster Resilient Primary Education in Bangladesh: Key Issues, Problems and Priorities. Save the Children UK and Plan International.

[4] Arredondo, J. (2016). Empowering the Poor Through Education in Bangladesh. The Borgen Project.

[5] BANBEIS. (1999). Bangladesh Education Statistics. Bangladesh Bureau of Educational Information and Statistics. Ministry of Education.

http://lib.banbeis.gov.bd/BANBEIS_PDF/Pub.No.58\%20Educatio n\%20System \%20of\%20Bangladesh\%20(Certificates, \%20Diploma ).pdf.

[6] BANBEIS. (2015). Bangladesh Education Statistics. Bangladesh Bureau of Educational Information and Statistics. Ministry of Education. http://data.banbeis.gov.bd/images/chap01.pdf.

[7] Bhadra, H. S. (2019, July). Flash Floods Hit Sylhet. Dhaka Tribune.

https://www.dhakatribune.com/bangladesh/nation/2020/06/27/flas h-flood-hits-sunamganj.

[8] Bhattacharya, B., \& Suman, A. (2012). Flash Floodcharacterization of the Haor area of Bangladesh. In $E G U$ General Assembly Conference Abstracts (p. 11287).

[9] BRAC. (2019). Floating the Light of Education in Haor. BRAC Education Programme. https://educateachild.org/sites/default/files/docs/2020//Boat\%20Sc hool_final.pdf.

[10] BWDB. (2014). ANNUAL FLOOD REPORT 2014, Flood Forecasting and Warning Centre (Bangladesh Water Development Board). http://www.ffwc.gov.bd/images/annual14.pdf.

[11] Chang, M. S., Khatoon, Z. S., \& Shah, S. A. (2013). Flood disasters and its impacts on child education in Sindh: a case study of 2010 flood. Int. J. Adv. Res, 1(3), 329-344.

[12] Coronese, M., Lamperti, F., Keller, K., Chiaromonte, F., \&Roventini, A. (2019). Evidence for sharp increase in the economic damages of extreme natural disasters. Proceedings of the National Academy of Sciences, 116(43), 21450-21455.

[13] Deshwara, M. (2016, July 23). Sunamganj schools hit hard by flood. The Daily Star. https://www.thedailystar.net/backpage/sunamganj-schools-hithard-flood-1258441.

[14] Deshwara, M., \& Eagle, A. (2017, August 5). School closed for 5 months a year for monsoon flood. The Daily Star. https://www.thedailystar.net/city/school-closed-5-months-yearmonsoon-flood-1444360.

[15] Education Cluster. (2015). Education in Emergency: Exploring Options for Continued Education during Disasters in Bangladesh. NIRAPAD

[16] GoB. (2012). Millennium Development Goals: Bangladesh Progress Report 2011. General Economic Division (GED), Bangladesh Planning Commission. Available at 
https://www.undp.org/content/dam/undp/library/MDG/english/M DG\%20Country\%20Reports/Bangladesh/MDG\%20Progress\%20R eport\%2011.pdf.

[17] Hasnat, M. A. (2017, August 18). Flood disrupts school education across the country. Dhaka Tribune. https://www.dhakatribune.com/bangladesh/education/2017/08/18/f lood-disrupts-school-education-across-country.

[18] INEE. (2010). Minimum Standards for Education: Preparedness, Response, Recovery. Inter-Agency Network for Education in Emergencies. 2nd Edition, New York: INEE.

[19] Kamruzzaman, M., \& Shaw, R. (2018). Flood and sustainable agriculture in the Haor basin of Bangladesh: A review paper. Universal Journal of Agricultural Research, 6(1), 40-49.

[20] Khan, A. M., \& Islam, I. (2010). Education and development in Bangladesh: A study from spatial perspective. Journal of Bangladesh Institute of Planners ISSN, 2075, 9363.

[21] Mohajan, H. (2014). Child rights in Bangladesh. Journal of Social Welfare and Human Rights, 2(1).

[22] Nipa, S. N. \& Ahmed, J, K. (2017). An Assessment of Flash Flood'17 Impact in Haor Areas of Bangladesh. BRAC. https://www.bracu.ac.bd/news/assessment-flashflood $\%$ E2\% 80\% 9917 -impact-Haor-areas-bangladesh.

[23] NPDM. (2017). National Plan for Disaster Management (20162020).Ministry of Disaster Management and Relief (MoDMR).https://modmr.portal.gov.bd/sites/default/files/files/mod mr.portal.gov.bd/policies/0a654dce_9456_46ad_b5c4_15ddfd8c4c 0d/NPDM(2016-2020)\%20-Final.pdf. Accessed 19 March 2020.

[24] Okuom, H. A., Simatwa, E. M., Maureen, O. A., \&Wichenje, K. M. (2012). Assessment of factors that contribute to repetition and dropout of pupils in primary schools in flood prone areas of Nyando District, Kenya: An analytical study. Educational Research, 3(2), 190-201.

[25] Peek, L. (2008). Children and disasters: Understanding vulnerability, developing capacities, and promoting resilienceAn introduction. Children Youth and Environments, 18(1), 1-29.

[26] Quayyum, M. A., \& Chowdhury, O. M. A. (2017, September 3). Natural disasters and uninterrupted education. The Daily Star. https://www.thedailystar.net/op-ed/natural-disasters-anduninterrupted-education-1280044.

[27] Roy, S., Huq, S., \& Rob, A. B. A. (2020). Faith and education in Bangladesh: A review of the contemporary landscape and challenges. International Journal of Educational Development, 79, 102290.

[28] Save the Children. (2017). Education Disrupted, Education Denied. https://www.preventionweb.net/publications/view/55206.

[29] Shah, A. A., Ye, J., Pan, L., Ullah, R., Shah, S. I. A., Fahad, S., \& Naz, S. (2018). Schools' flood emergency preparedness in khyber Pakhtunkhwa province, Pakistan. International Journal of Disaster Risk Science, 9(2), 181-194.

[30] Shohel, M. \&Mahruf C. (2012). Childhood Poverty and Education in Bangladesh: Policy implications for disadvantaged children, Innocenti Working Papers no. 2012-10.

[31] Trines, S. (2019). Education in Bangladesh. World Education Services (WES). https://wenr.wes.org/2019/08/education-inbangladesh.

[32] UNDP. (2019). Sustainable Development Goals. United Nations Development Programme. Available at https://sdgs.un.org/goals.

[33] UNDRR. (2017). he Comprehensive School Safety framework. United Nations Office for Disaster Risk Reduction (UNDRR). Available at https://www.undrr.org/publication/comprehensive-school-safety.

[34] UNICEF. (2018). Child Friendly Spaces (CFS) Minimum Standards. Protection Cluster of UNICEF. Available at https://reliefweb.int/sites/reliefweb.int/files/resources/cfs_minimu m_standard_-_cxb_cpss_2018.pdf.

[35] UNISDR. (2015). Indicators to monitor global targets of the Sendai Framework for Disaster Risk Reduction 2015-2030: A technical review. Geneva: United Nations Office for Disaster Risk Reduction.

[36] Wisner, B., Blaikie, P., Blaikie, P. M., Cannon, T., \& Davis, I. (2004). At risk: natural hazards, people's vulnerability and disasters. Psychology Press.

[37] World Bank. (2013). Bangladesh Education Sector Review; Seeding Fertile Ground-Education That Works for Bangladesh. World Bank Office, Dhaka.

[38] World Bank. (2015). Millennium Development Goals. http://www5.worldbank.org/mdgs/education.html.

[39] World Bank. (2018). Bangladesh: Reducing Poverty and Sharing Prosperity. Result Briefs. Available at https://www.worldbank.org/en/results/2018/11/15/bangladeshreducing-poverty-and-sharing-prosperity 